\title{
Changes in angiotensin-converting enzyme activity in lungs damaged by the pyrrolizidine alkaloid monocrotaline
}

\author{
W MARK LAFRANCONI, RYAN J HUXTABLE \\ University of Arizona Department of Pharmacology, Tucson, Arizona, USA
}

ABSTRACT Administration of monocrotaline, a pyrrolizidine alkaloid, to male Sprague-Dawley rats for up to three weeks increased dry lung weights by $64 \%$ and reduced the specific activity of lung angiotensin-converting enzyme activity by $64 \%$. When the total activity per lung is calculated, however, there is no significant difference between control and monocrotaline-treated animals. The decrease in specific activity is due to increase in total lung protein (52\% above control) and not to an actual reduction in the total angiotensin-converting enzyme activity in the lung.

Kay and his colleagues recently reported that pulmonary angiotensin-converting enzyme activity was reduced in monocrotaline-induced pulmonary hypertension ${ }^{12}$. We had conducted similar work in whole lungs ${ }^{3}$ and lung microsomes and had also been able to show a decrease in the activity of this enzyme when this was expressed per milligram of microsomal protein. Our conclusions, however, differ from those of Kay et al. ${ }^{12}$

\section{Methods}

Male Sprague-Dawley rats, with initial body weights of $50 \mathrm{~g}$, were treated with monocrotaline in their drinking water $(20 \mathrm{mg} / \mathrm{l})$ for up to three weeks. Control animals received tap water. Angiotensinconverting enzyme activity was determined in protein fractions obtained by differential centrifugation. ${ }^{4}$ Lungs were homogenised in $0.25 \mathrm{~mol} / \mathrm{l}$ sucrose containing $1 \mathrm{mmol} / \mathrm{l}$ magnesium sulphate, then centrifuged at $3000 \mathrm{~g}$ for 10 minutes. The resulting supernatant was centrifuged at $9000 \mathrm{~g}$ for 20 minutes. The angiotensin-converting enzyme activity was further enriched by centrifugation of the $9000 \mathrm{~g}$ supernatant at $100000 \mathrm{~g}$ for 90 minutes. The resulting pellet was suspended in buffer containing $100 \mathrm{mmol} / \mathrm{l}$ boric acid and $300 \mathrm{mmol} / \mathrm{l}$ sodium

Address for reprint requests: Dr Ryan J Huxtable, University of Arizona Department of Pharmacology, Health Sciences Center, Tucson, Arizona 85724, USA. chloride ( $\mathrm{pH} \mathrm{8.2)} \mathrm{and} \mathrm{the} \mathrm{angiotensin-converting}$ enzyme activity was determined..$^{5}$ The total recoverable angiotensin-converting enzyme activity was calculated for the entire $100000 \mathrm{~g}$ pellet. Protein was estimated in lung fractions according to the methods of Lowry et al. ${ }^{6}$

\section{Results}

Monocrotaline, administered by various routes, significantly increases dry lung weight. ${ }^{37}$ Animals maintained on drinking water containing monocrotaline $(20 \mathrm{mg} / \mathrm{l})$ developed a $64 \%$ increase in dry lung weight and a $52 \%$ increase in protein content. In these experiments the lung protein mass was significantly raised above control values by day 10 (fig 1), which was the time at which a decrease in specific angiotensin-converting enzyme activity per unit mass of protein became apparent (fig 2). When expressed as a percentage of control (fig 3 ) a plot is generated similar to that reported by Kay et al in their figure $5 .^{1}$ When we calculate the total recoverable angiotensin-converting enzyme activity for the entire lung, however, there is no change in activity between monocrotaline-treated and control groups (fig 4). Thus when angiotensin-converting enzyme activity is measured and expressed as a function of microsomal protein there is a decrease, but this is due to dilution of activity by the increased mass of the lung and a three-fold increase in recoverable microsomal protein. 
Monocrotaline-induced changes in lung dry weight and specific angiotensin-converting enzyme ( $A C E)$ activity. Rats received either monocrotaline in their drinking water for the number of days indicated (O) or tap water (O). Each point represents the mean value $\pm S D$ for six animals. ${ }^{*} p<0.05$ compared with control value (Student's unpaired two-tailed t test).

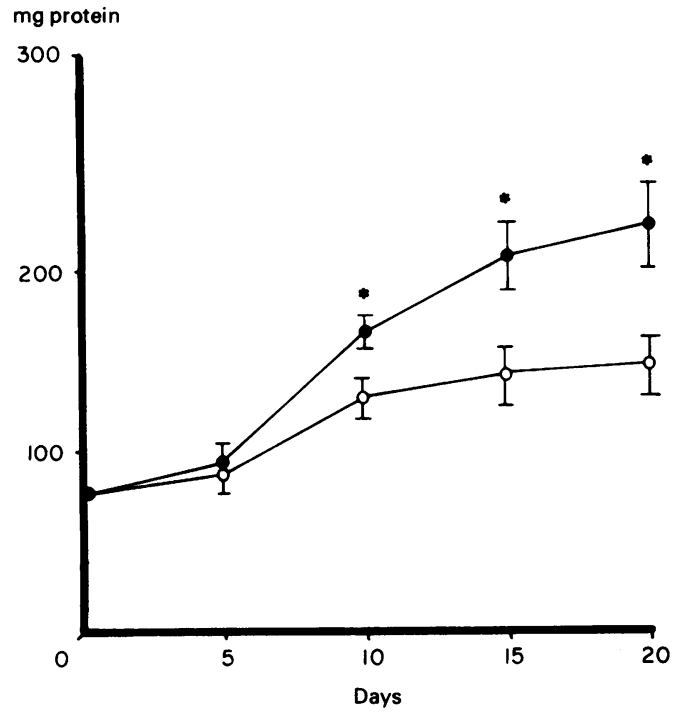

Fig 1 Changes in total trichloroacetic acid precipitable material in lung (lung dry weight) as a function of time.

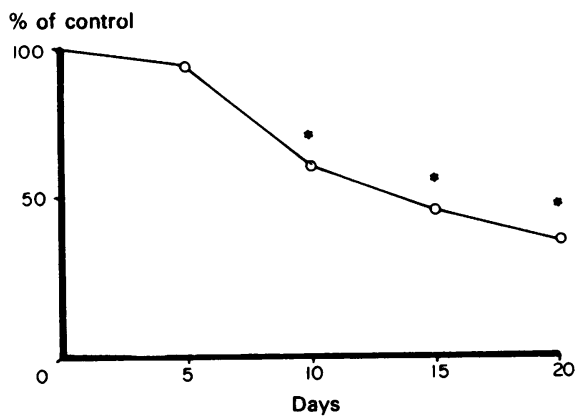

Fig 3 ACE activity per mg protein as a percentage of control.

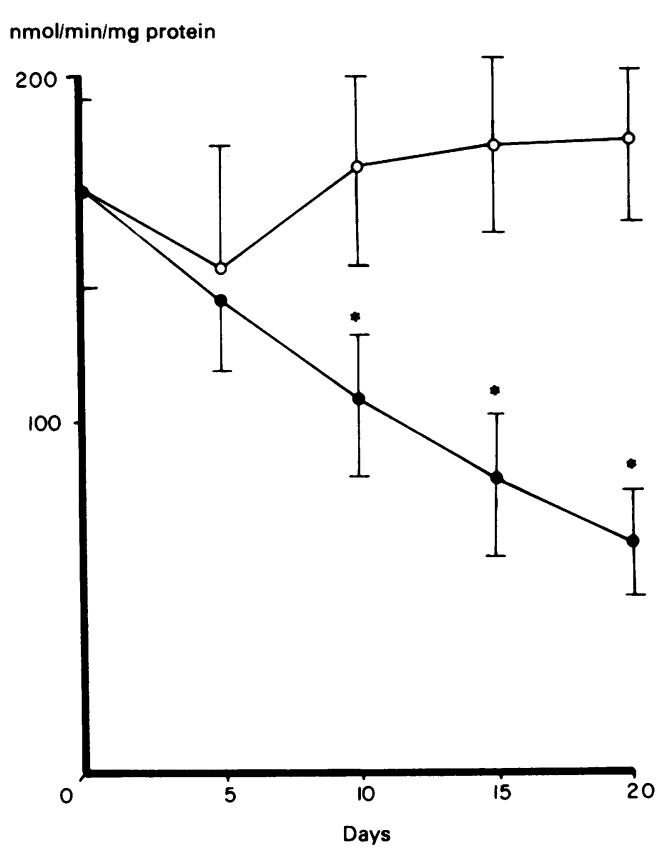

Fig 2 Changes in ACE activity per mg protein as a function of time.

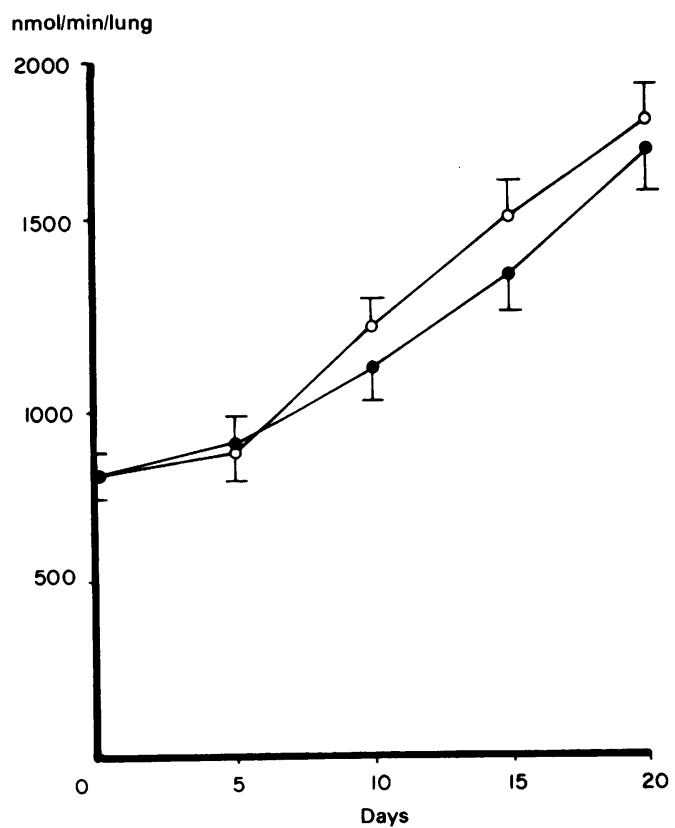

Fig 4 Total ACE activity expressed per lung. 
Changes in rat lung weight, protein content, and angiotensin-converting enzyme (ACE) activity after 21 days' treatment with monocrotaline

\begin{tabular}{|c|c|c|c|c|c|c|}
\hline & $\begin{array}{l}\text { Wet weight } \\
(m g)\end{array}$ & $\begin{array}{l}\text { Dry weight* } \\
(m g)\end{array}$ & $\begin{array}{l}\text { Total lung } \\
\text { protein (mg) }\end{array}$ & $\begin{array}{l}\text { Total microsomal } \\
\text { protein }(\mathrm{mg})\end{array}$ & $\begin{array}{l}\text { ACE activity } \\
\text { per } m g \text { protein } \dagger\end{array}$ & $\begin{array}{l}\text { Total } A C E \\
\text { activity in } \\
\text { microsomal pellet } \ddagger\end{array}$ \\
\hline \multirow{2}{*}{$\begin{array}{l}\text { Control }(n=12) \\
\text { Monocrotaline-treated } \\
(n=8)\end{array}$} & $1005 \pm 57$ & $174 \pm 6$ & $149 \pm 16$ & $10 \pm 1$ & $181 \pm 22$ & $1824 \pm 109$ \\
\hline & $1556 \pm 191 \S$ & $286 \pm 7 \S$ & $227 \pm 24 \S$ & $28 \pm 5 \S$ & $65 \pm 14 \S$ & $1764 \pm 128$ \\
\hline
\end{tabular}

*Values obtained from Huxtable $t t_{\text {al. }}{ }^{3}$

$\dagger \mathrm{nmol} / \mathrm{min} / \mathrm{mg}$ protein

$\ddagger \mathrm{nmol} / \mathrm{min} /$ total microsomes

$\$ \mathrm{p}<0.05$ compared with controls (Student's $t$ test).

\section{Discussion}

Activities based on protein normalisations are valid only when the weights or protein contents of the organs are unchanged. The lung frequently responds to injury by an increase in protein content, either through accumulation of exogenous protein or through increased protein synthesis. ${ }^{8}$ For a true evaluation of changes in activities of enzymes such as angiotensin-converting enzyme the data need to be presented as a function of the whole organ. With angiotensin-converting enzyme measurements this is difficult because the activity of the crude lung homogenate is quite low and possibly contaminated with non-specific peptidases. ${ }^{9}$ To measure the activity accurately, enrichment of the enzyme by differential centrifugation is necessary. This step introduces some variability into the assay. In addition, the activity is measured in a protein sample that is a fraction of the original protein, which also makes it difficult to extrapolate to activities for the entire lung. Despite these limitations, we calculated angiotensin-converting enzyme activity per lung based on the total activity of the pellet recovered after the $100000 \mathrm{~g}$ spin because the enzyme activity per whole organ is more meaningful than the activity expressed per unit of protein (table).

In conclusion, subacute administration of monocrotaline produces in the lungs and right heart all the changes seen after acute administration. These include pulmonary arterial hypertension, ${ }^{10}$ right ventricular hypertrophy, increased lung mass, endothelial hyperplasia, and inhibition of serotonin transport. ${ }^{3}$ Inhibition of norepinephrine transport is seen with more severe damage. ${ }^{11}$ We have not seen inhibition of endothelial $5^{\prime}$-nucleotidase or angiotensin-converting enzyme activities.

This work was supported by United States Public Health Service grant HL 25258 and National Insti- tute of Environmental Health Sciences grant 1-T-32-ESO-7091.

\section{References}

'Kay JM, Keane PM, Suyama KL, Gauthier D. Angiotensin-converting enzyme activity and evolution of pulmonary vascular disease in rats with monocrotaline pulmonary hypertension. Thorax 1982;37:88-96.

${ }^{2}$ Keane PM, Kay JM, Suyama KL, Gauthier D, Andrew $\mathrm{K}$. Lung angiotensin-converting enzyme activity in rats with pulmonary hypertension. Thorax 1982;37:198-204.

${ }^{3}$ Huxtable R, Ciaramitaro D, Eisenstein D. The effect of a pyrrolizidine alkaloid, monocrotaline, and a pyrrole, dehydroretronecine, on the biochemical function of the pulmonary endothelium. Mol Pharmacol 1978;14:1189-203.

${ }^{4}$ Roth M, Depierre D. Dipeptidyl carboxypeptidase in lung and blood plasma. In: F Junod, Rodolphe de Haller, eds. Lung metabolism. New York: Academic Press, 1975.

${ }^{5}$ Cushman DW, Cheung HS. Spectrophotometric assay and properties of the angiotensin-converting enzyme of rabbit lung. Biochem Pharmacol 1971;20:1637-48.

${ }^{\circ}$ Lowry OH, Rosebrough NJ, Forr AE, Randall RJ. Protein measurement with the Folin phenol reagent. $J$ Biol Chem 1951;193:265-75.

${ }^{7}$ Roth RA, Dotalf LA, Baranyi B, Kuo CH, Hook JB. Effect of monocrotaline ingestion on liver, kidney and lungs of rats. Tox Appl Pharmacol 1981;60:193-203.

${ }^{8}$ Witschi H. Pulmonary responses to toxic agents. CRC Crit Rev Toxicol 1977;5:23-66.

${ }^{9}$ Bakhle YS. The nature of the bradykinin inactivating system in isolated lungs. $\mathrm{Br} J$ Pharmacol 1976;56:349-50.

${ }^{10}$ Huxtable R, Paplanus S, Laugharn J. The prevention of monocrotaline induced right ventricular hypertrophy. Chest 1977;715:308-10.

$"$ Gillis CN, Huxtable RJ, Roth RA. Effect of monocrotaline pretreatment of rats on removal of 5-hydroxytryptamine and norepinephrine by perfused lung. Br J Pharmacol 1978;63:435-43. 